\title{
タバココナジラミ成虫の施設内における 垂直方向と水平方向への分散
}

\author{
三 宅 律 幸 \\ （愛知県農業総合試験場）
}

愛知県では, タバココナジラミBemisia tabaci （Gennadius）が媒介するトマト黄化葉巻病と, その吸汁 による各種作物の生育抑制，そしてすす病の発生等が問 題になっている ${ }^{3)}$ 。タバココナジラミ成虫は黄色に誘引 されるため ${ }^{2,4)}$, 黄色粘着板は発生予察用として, また施 設栽培では誘殺のためにも利用されている。しかし，効 果的に誘殺するための黄色粘着板の利用方法は, 詳しく 調査されていない。そこで, 黄色粘着板を利用する場合 の効果的な設置距離と設置位置を明らかにするため, 施 設内においてタバココナジラミ成虫の垂直方向と水平方 向への分散を調査した。

\section{調 査方 法}

\section{1. 垂直方向の分散試験}

愛知農総試内のタバココナジラミ成虫（バイオタイプ B : Q 比26 : 5) が発生しているシソ施設で実施した。供 試施設は, ビニル被覆で面積 $0.66 \mathrm{a}$ (間口 $5.5 \mathrm{~m}$, 奥行 き $12 \mathrm{~m}$, 軒高 $3.0 \mathrm{~m}$ ) の 1 連南北棟で南北出入り口と東 西側面は $0.4 \mathrm{~mm}$ 目の防虫ネットを設置した。施設中央 にシソの草高と同じ高さの台に載せた高さ $180 \mathrm{~cm}$ の木 製支柱 1 本を設置し，下端 $30 \mathrm{~cm}$ の位置から $30 \mathrm{~cm}$ 間隔 で高さ $180 \mathrm{~cm}$ まで黄色粘着板（商品名：虫とり君，長 さ $24 \mathrm{~cm} \times$ 幅 $10 \mathrm{~cm}$ ）の粘着面を下に向け，地面と水平 に互い違いに東西に 6 枚取り付けた（第 1 図）。タバコ コナジラミ成虫の誘殺数調查は，8月 4 日から10月21日 までの期間に, おおむね 1 日から 2 日間隔で 30 回行った。 そして, 黄色粘着板は調査後に毎回交換した。また, 毎 回黄色粘着板設置前に，シソ上位展開葉を 1 株当たり 1 葉, 合計 30 葉のタバココナジラミ成虫寄生数を調査した。

\section{2. 水平方向の分散試験}

愛知農総試内の作物の栽培されていないビニル被覆施 設で面積 $1.4 \mathrm{a}$ (間口 $6.65 \mathrm{~m}$, 奥行き $21 \mathrm{~m}$, 軒高 $4.3 \mathrm{~m}$ ) の 1 連南北棟を利用した。施設の中央にタバココナジラ
ミバイオタイプ B の多数の幼虫と成虫を寄生させた 1 株の鉢植えキャベツを置き, その草高 $30 \mathrm{~cm}$ 上方に, 黄 色粘着板（同上）の下端がくるように垂直に設置した。 さらにその東西南北方向に $30 \mathrm{~cm}$ 間隔で各方向に 5 枚ず つ, 合計 21 枚の黄色粘着板を同じ高さに取り付けた（第 2 図)。また, 黄色粘着板は東西方向に設置した場合は 粘着面を東西に, 南北方向に設置した場合は粘着面を南 北に向け設置した。そして, キャベツ上では南北に向け 設置し，第 5 図では南側を内側，北側を外側と表した。

タバココナジラミ成虫の誘殺数調査は，9月 1 日から 10月 1 日までの期間に，おおむね 1 日から 3 日間隔で 15 回行った。そして, 黄色粘着板は調査後に毎回交換した。 また，調査開始後に黄色粘着板の上下でタバココナジラ ミ成虫の誘殺効率に違いがあることが分かったため，9

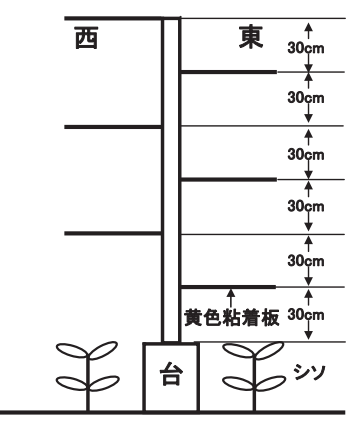

第 1 図 黄色粘着板の垂直方向への設置図 台の高さはシソの草高が伸びるたびに高くした。

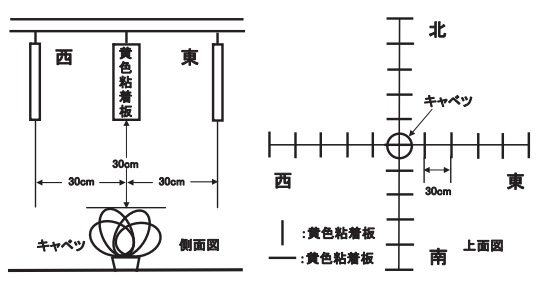

第2 図 黄色粘着板の水平方向への設置図

Noriyuki Miyake (Aichi-Pref. Agri. Res. Ctr.): Vertical and horizontal dispersions of adult sweetpotato whitefly, Bemisia tabaci (Gennadius), in greenhouse 2009年 2 月 18 日受理 
月11日以降の11回の調査では，タバココナジラミ成虫の 誘殺数を黄色粘着板内の高さ別でも調査した。すなわち, 高さ $24 \mathrm{~cm} \times$ 幅 $10 \mathrm{~cm}$ の黄色粘着板の下端から上方へ の粘着面積を，下端から上方への長さ $0-4 \mathrm{~cm}, 4-8 \mathrm{~cm}$, 8-16 cm，16-24 cm の位置で分け，それぞれ下端 1 （粘 着面積 $40 \mathrm{~cm}^{2}$ ), 下端 2 (粘着面積 $40 \mathrm{~cm}^{2}$ )，中間（粘 着面積 $80 \mathrm{~cm}^{2}$ ） と上端（粘着面積 $80 \mathrm{~cm}^{2}$ ）に分けて調 查した。

\section{1. 垂直方向の分散試験}

\section{結果および考察}

黄色粘着板によるタバココナジラミ成虫の総誘殺数は 5,707 頭で，1 日当たり誘殺数は，シソの草高 $30 \mathrm{~cm}$ 上 方が最も多く, $180 \mathrm{~cm}, 60 \mathrm{~cm}, 150 \mathrm{~cm}, 120 \mathrm{~cm}, 90 \mathrm{~cm}$ の順で減少し， $30 \mathrm{~cm}$ 上方の誘殺数とそれ以上の高さの 誘殺数との間にはおおむね統計的に有意な差があった (第 3 図)。また，1 日当たりの総誘殺数が多くなると, 1 葉当たり寄生数が多くなる傾向にあり, 高さ $30 \mathrm{~cm}$ 上 方の 1 日当たり誘殺数と 1 葉当たり寄生数で最も高い相 関 $(\mathrm{r}=0.705, P<0.01)$ があった（第 4 図）。黄色粘着 板は，寄生植物の真上 $30 \mathrm{~cm}$ の位置でタバココナジラミ 成虫を最も多く誘殺し，寄生植物に近いほど誘引効果が 高いと考えられた。また，草高 $180 \mathrm{~cm}$ 上方の位置で 2 番目に多く誘殺されたことから，施設内のかなり高い空

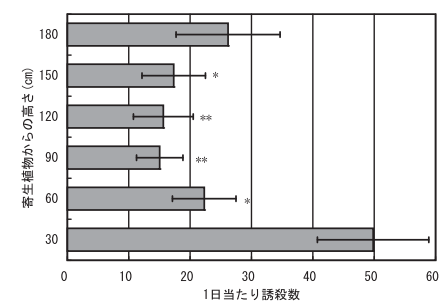

第3 図 黄色粘着板による垂直方向のタバココナジラミ成虫誘 殺数

棒グラフのバーは標準誤差を示す。**, *高さ $30 \mathrm{~cm}$ と の間で有意な差があることを示す (Tukey-Kramer test, ** $P<0.01$, * $P<0.05$ )。

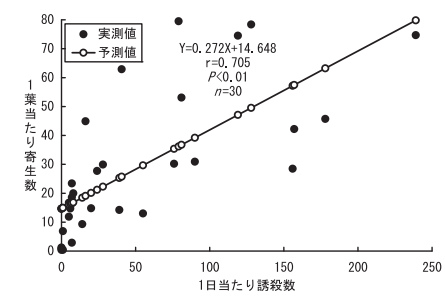

第4図 垂直方向の高さ $30 \mathrm{~cm}$ に設置した黄色粘着板による夕 バココナジラミ成虫の 1 日当たり誘殺数と 1 葉当たり 寄生数との関係
間でも多数が飛翔していることが考えられた。

\section{2. 水平方向の分散試験}

黄色粘着板によるタバココナジラミ成虫の総誘殺数は 2,972頭で，中心部 $(0 \mathrm{~cm})$ が最も多く，東西南北とも 中心から離れるにしたがって減少していく傾向にあった (第 5 図)。中心から $30 \mathrm{~cm}$ までの誘殺数と $60 \mathrm{~cm}$ 以上離 れた位置の誘殺数との間には統計的に有意な差があった (Tukey-Kramer test, $P<0.01$ )。

黄色粘着板内の高さ別の総誘殺数は，1,563頭（下端 1 : 748頭, 下端 2 : 362頭，中間 : 276頭，上端：177頭） で，上端いくほど減少した。また，中心から離れるにつ れて誘殺数は減少したが，下端では著しく減少したのに 対し，元々誘殺数の少なかった中間・上端の減少率は小 さかった（第 6 図）。タバココナジラミ成虫は, 寄生植 物に近い黄色粘着板の下端に多く誘殺され，水平方向に 離れるにしたがって誘殺位置は上方に移動した。これは, 飛翔直後は最も近い黄色部分に誘引されるが，寄生植物 から飛翔により離脱し, その飛翔高度が上昇することに より，誘引される位置が上方に変化すると思わ机た。

オンシツコナジラミ成虫の場合は，施設内で黄色粘着 板に垂直方向では $30 \mathrm{~cm}$ の近距離で多く捕虫され, 水平 方向では黄色粘着板との距離が隔たるほど誘引，捕虫さ れた虫数は少なく, 距離と捕虫率の間には負の関係が認 められており ${ }^{1)}$, 最大の誘引距離は $1 \mathrm{~m}$ 前後と推察され ている ${ }^{5)}$ 。今回の実験により，タバココナジラミに対し て黄色粘着板を利用する場合の効果的な誘引距離は, 垂 直方向では寄生植物の上方 $30 \mathrm{~cm}$ 以内に粘着面を下方に 向けて設置し，水平方向では寄生植物の側方 $30 \mathrm{~cm}$ 以内
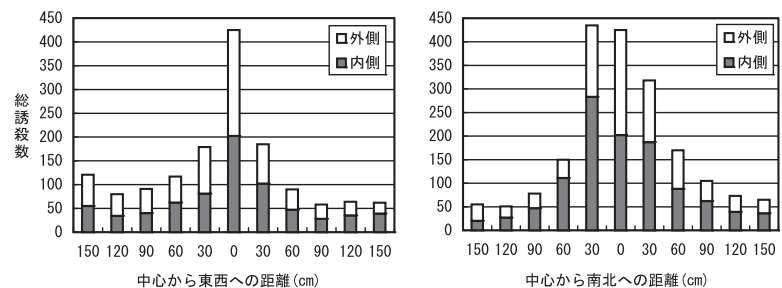

第 5 図 黄色粘着板による水平方向のタバココナジラミ成虫の 総誘殺数

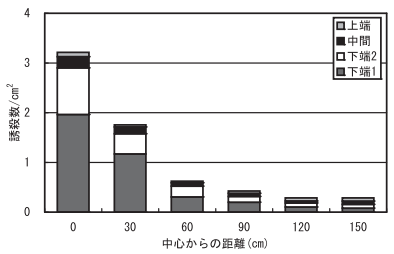

第6 図 水平方向に黄色粘着板を並べた場合の粘着板内の位置 別タバココナジラミ成虫の誘殺数 
に粘着面を寄生植物に向けて横向き垂直に設置すれば良 いものと考えられた。ただし，作物の栽培方法によって は，黄色粘着板の設置位置が作業の妨げとなる場合もあ り，理想的な設置方法を実施することができない場合が あるため, 今後は作物ごとに現実的な設置方法を検討す る必要がある。

\section{引用文献}

1）荻谷俊一（1982）関東東山病虫研報 $29: 145-146$.

2) 林 英明 (1999) 植物防疫 $53: 226-228$.

3）飯田史生（2005）今月の農薬 49(2)：24-29.

4）三宅律幸 - 加藤昌章 - 山下重樹（1991）関西病虫研報 $33: 84$.

5）矢野栄二・腰原達雄（1984）野菜試報 A12：85-96. 